Article

\title{
Monitoring Mediterranean Oak Decline in a Peri-Urban Protected Area Using the NDVI and Sentinel-2 Images: The Case Study of Castelporziano State Natural Reserve
}

\author{
Fabio Recanatesi ${ }^{1, *}$, Chiara Giuliani ${ }^{2}$ and Maria Nicolina Ripa ${ }^{1}$ (I) \\ 1 Department of Agricultural and Forestry Sciences (D.A.F.N.E.), Tuscia University, 01100 Viterbo, Italy; \\ n.ripa@unitus.it \\ 2 Department Landscape and Planning, La Sapienza University, 00185 Rome, Italy; \\ chiara.giuliani@uniroma1.it \\ * Correspondence: fabio.rec@unitus.it; Tel.: +39-0761-357250
}

Received: 16 July 2018; Accepted: 13 September 2018; Published: 16 September 2018

\begin{abstract}
Climate change and human activities in particular are important causes of the possible variations in Mediterranean basin forest health conditions. Over the last decades, deciduous oak-forest mortality has been a recurrent problem in central and southern Italy. Despite the perception of increasingly visible damage in oak forests in drought sites, the role of various environmental factors in their decline is not completely clear. Among the modern methods of monitoring terrestrial ecosystems, remote sensing is of prime importance thanks to its ability to provide synoptic information on large areas with a high frequency of acquisition. This paper reports the preliminary results regarding a replicable and low cost monitoring tool planned to quantify forest health conditions based on the application of the Normalized Difference Vegetation Index (NDVI), using the diachronic images provided by the Sentinel-2 satellite. The study area is represented by a peri-urban forest of natural Mediterranean deciduous oaks, characterized by a high variability in the composition of the species and in the silvicultural structures. In order to monitor the health conditions of a specific forest canopy cover with remote sensing data, it is necessary to classify the forest canopy cover in advance to separate it from other species and from the Mediterranean scrub. This is due to the spatial distribution of vegetation and the high rate of biodiversity in the Mediterranean natural environment. To achieve this, Light Detection and Ranging (LiDAR) data, forest management data and field sampling data were analyzed. The main results of this research show a widespread decline in oak health conditions over the observed period (2015-2017). Specifically, for the studied area, thanks to the specific localization of the oak canopy cover, we detected a high potential concerning the Sentinel-2 data application in monitoring forest health conditions by NDVI application.
\end{abstract}

Keywords: NDVI; Sentinel-2; oak-decline; Mediterranean forest management; Castelporziano

\section{Introduction}

Forest ecosystems are an essential economic and environmental resource widespread in most regions of the world. In the Mediterranean basin, a region characterized by long droughts, extreme weather events, a generally low precipitation rate coupled with fragile land susceptible to degradation processes (e.g., erosion, salinization, pollution, sealing) and human pressure due to the continuous development of both scattered and compact urban settlements, it is possible to identify a wide range of disturbing factors that threaten natural forests. 
For these reasons, the Mediterranean basin has been identified as one of the hot spots of climate change with major risks in the near future, including warmer and drier conditions. These trends would imply that more forest areas will become particularly vulnerable in drier conditions [1].

In this context, it is widely acknowledged that the oak-decline is a phenomenon that has been underway in Southern Europe since at least the early 1980s [2-5]. In Italy, since the 1980s, drought-induced deaths have been detected in the southern regions of oak forests, which show a worrying trend of increasing damage, as in other areas of the Mediterranean basin.

Oak-decline is widely recognized as a complex phenomenon due to multiple causes that occur slowly for several years, even if mortality can suddenly follow, the decline and the hydraulic failure caused by drought is considered the main mechanism responsible for a generalized decline. It can be explained by two non-mutually exclusive mechanisms: (i) hydraulic failure due to a drastic loss of conductivity of the xylem; and (ii) carbon deficiency when the carbon demands are not met [6-8].

In this context of environmental change due to the climate and, especially in the Mediterranean basin, due to human activities, the arrangement of easily replicable methodologies useful in monitoring health conditions could represent an efficient tool to support decision makers in planning efficient strategies for recovery of these environments.

In this regard, the application of vegetation indices (VIs) by means of remote sensing of multispectral images represents an efficient tool for monitoring the health conditions of forests.

Additionally in the Mediterranean environment, where forest structures often represent a limiting factor in the application of remote sensing data due to their spatial resolution, the recent availability of multispectral satellite data, provided by ESA (European Space Agency, Paris, France), represents a step ahead in monitoring forest conditions in the Mediterranean area.

In fact, in the last few decades, the spatial resolution of satellite multispectral data has constantly increased. Since 1982, Landsat Thematic Mapper (TM) has collected images with a spatial resolution of $30 \mathrm{~m}$. Since 1986, SPOT XS has had a resolution of $20 \mathrm{~m}$, and the Sentinel mission has provided multispectral images at $10 \mathrm{~m}$ since 2015.

Moreover, with the emergence of satellite images at very high spatial resolution, the spatial resolution gap between satellite images and aerial photographs has decreased [9-13].

Regarding the development of VIs, scientists working in this field have developed several indices for qualitatively and quantitatively evaluating vegetative cover using multi-spectral data. In fact, over forty vegetation indices have been developed during recent decades, amongst which the NDVI is the most widely used in monitoring general health conditions of forest surfaces. The degree of vigor in forest vegetation cover can be classified according to its spectral response, which when in red (630-690 nm) is strongly correlated with chlorophyll concentration, while the spectral response in near infrared $(760-900 \mathrm{~nm})$ is correlated by the leaf area index and green vegetation density. Thanks to these properties, the NDVI can be utilized as an indicator of possible vegetation stress, particularly that due to water shortage or pest diffusion. For these reasons, in the beginning phase of the monitoring, we preferred to use the NDVI index to obtain a comparable result with others similar study cases [14-20].

This paper aims to evaluate the use of remote sensing data to follow the multi-year evolution of a Mediterranean natural forest ecosystem in a protected area of central Italy, the Presidential Estate of Castelporziano (Rome).

For the Mediterranean environment, the availability of a methodology capable of efficiently extracting NDVI values of deciduous oak from satellite images is a necessary basis for producing accurate long-term data series that characterize this ecosystem in the study area.

\section{Materials and Methods}

\subsection{The Study Area}

The Presidential Estate of Castelporziano $\left(41^{\circ} 44^{\prime} 37^{\prime \prime} \mathrm{N}-12^{\circ} 24^{\prime} 00^{\prime \prime} \mathrm{E}\right)$, which today is a State Natural Reserve, is full of intact forests, mainly characterized by deciduous oaks and an entire 
sequence of different ecosystems: Dunes, Mediterranean scrub, ponds, meadows and pastures. It is an irreplaceable relic of the old Mediterranean coastal environment, which today is mostly invaded by buildings, intensive agriculture, degraded steppe, marinas, bathing establishments and coastal roads, Figure 1.

Castelporziano has a total area of almost $60 \mathrm{Km}^{2}$, its territory is mainly represented by forest use, characterized by: deciduous oak forest $\left(40 \mathrm{Km}^{2}\right.$ ), evergreen oak forest (holm oak and cork oak-0.95 $\mathrm{Km}^{2}$ ) and pine-forest (Stone pine $-0.9 \mathrm{Km}^{2}$ ).
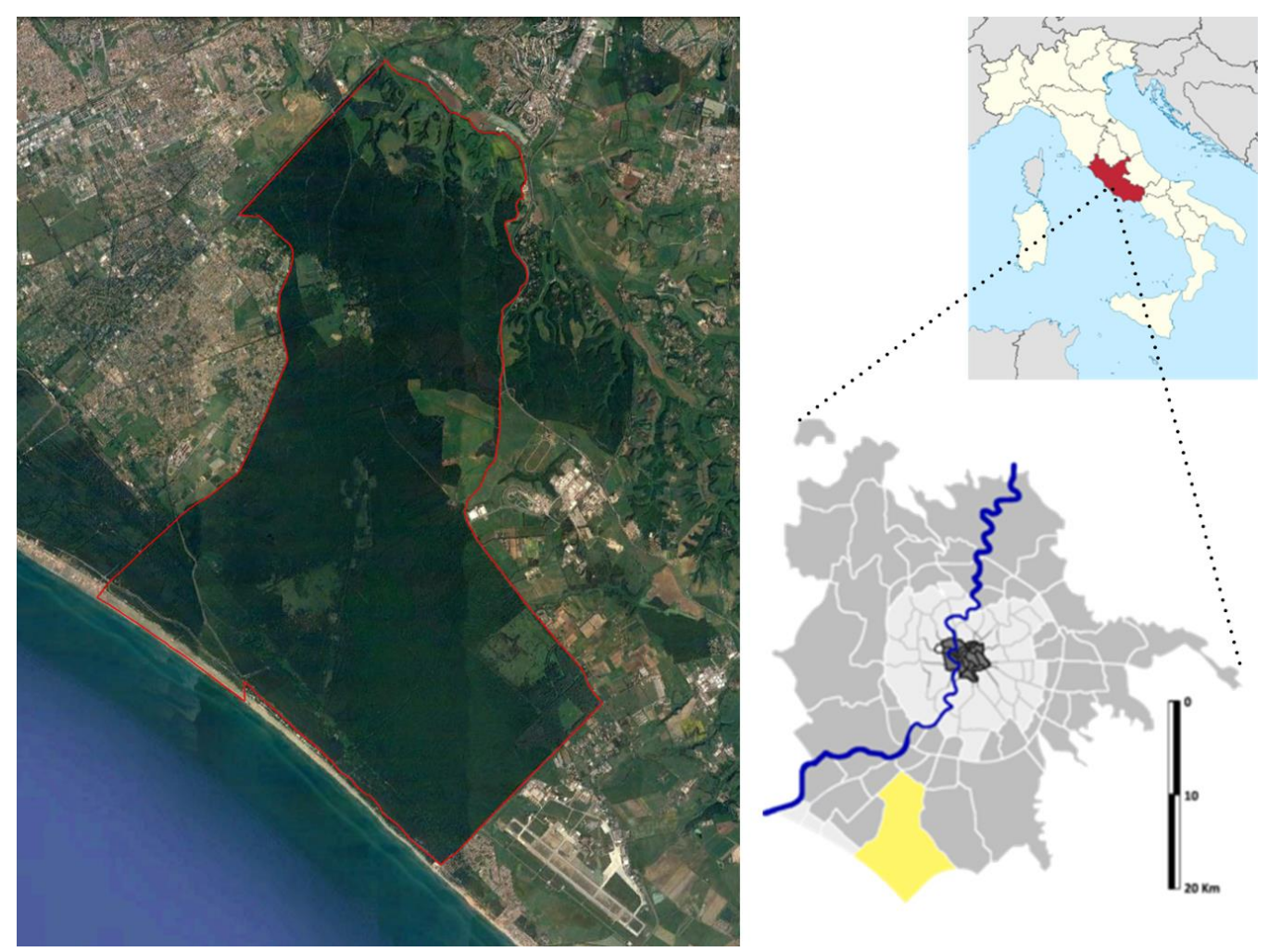

Figure 1. Study area of Castelporziano: on the left, aerial photo and borders (red line); on the right, a territorial description of the study area (yellow), Tiber river (blue), Municipality of Rome (dark gray), and city of Rome (light gray and black).

For these reasons, Castelporziano today represents a key area in the network of protected areas around the metropolitan territory of Rome, with particular attention to the conservation of biodiversity, soil conservation and the containment of urban expansion [21,22].

Regarding the location of deciduous oak forest in the study area of Castelporziano, in this research, we referred to the classification of forest types derived from the Forest Management Plan (FMP) for Castelporziano $[23,24]$ which is mainly characterized from broad-leaved Mediterranean oaks such as: Quercus robur, Quercus frainetto, Quercus pubescens and Quercus cerris.

In the FMP document, the deciduous oak forest has been classified into eight different forest types, each characterized by a different species composition; spatial density and silvicultural structure. In the deciduous oak forest of Castelporziano, despite the availability of an accurate set of georeferenced data, all available data refer to a forest management unit (FMU).

The tree canopy cover, in the deciduous oak forest of Castelporziano, due to its natural origin, presents a high variety in terms of spatial distribution, even at the scale of the FMU. This aspect is a limiting factor in the application of the remote sensing technique in providing the specific state of health for the deciduous oak trees in the FMU scale.

For these reasons, before applying the NDVI, a preliminary analysis of the forest canopies was carried out in the Geographic Information System (GIS) environment, to detect on the FMU scale, the 
actual covering layer of the canopy belonging to the deciduous oak forest. To reach this goal we used ArcMap GIS software to reclass the LiDAR data according to the different forest types and, in a second step, to apply the NDVI specifically for the deciduous oak canopy.

Figure 2 shows some examples concerning the heterogeneous distribution of deciduous oak tree found in four different FMUs.
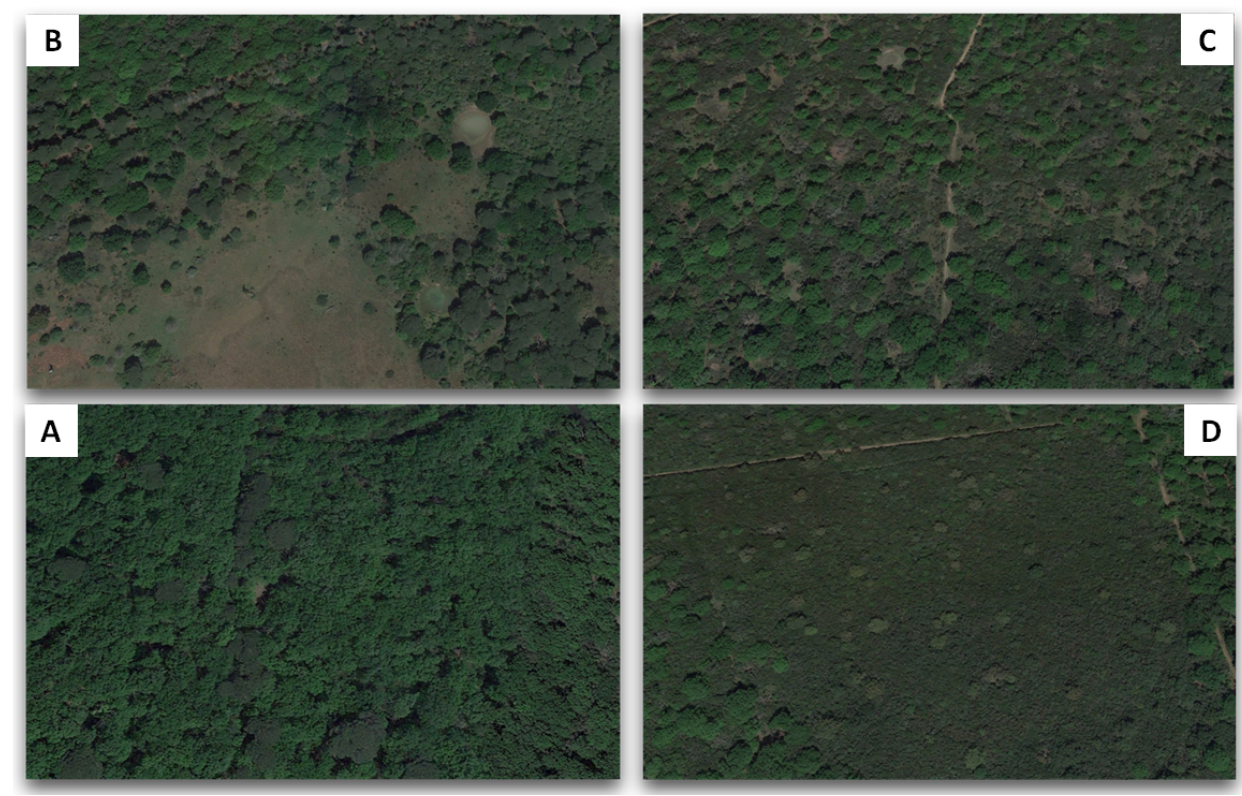

Figure 2. Different silvicultural structures detected in Castelporziano deciduous oak forest at forest management unit (FMU) scale. (A) Homogeneous canopy cover with presence of some evergreen oak (Q. ilex and $Q$. suber); (B) heterogeneous canopy cover with presence of some evergreen oak and bare soil; (C) low density of the deciduous oak canopy with Mediterranean scrub and bare soil; (D) isolated deciduous oaks trees in Mediterranean scrub.

\subsection{Climatic Drought in Castelporziano and Oak Forest Dieback}

Since the mid-1990s, a network of agro-climatic stations equipped with sensors for traditional meteorological measures and soil characteristics has been installed throughout the woodland of Castelporziano. The acquired data show that in the last thirty years the average temperature increased by almost $1.5^{\circ} \mathrm{C}$, while the rainfall has decreased by $80 \mathrm{~mm}$, although with a high variability over time $[25,26]$. Furthermore, as regards the management of water resources, the surrounding territory of Castelporziano is characterized by a high rate of soil sealing that limits the recharge of the water table [27]. Concerning the observed period, in the study area, the total rainfall and relative raining days are the following: year 2015, $6012 \mathrm{~mm}$ in 63 days; year 2016, $6552 \mathrm{~mm}$ in 79 days; year 2017, $6342 \mathrm{~mm}$ in 51 days.

This climate change scenario has contributed to the decline of the Castelporziano oak forest. In fact, in recent years, a widespread and progressive crown dieback has been observed, which threatens the whole functioning of the ecosystem and the ecological integrity of this typical Mediterranean landscape. Figure 3 shows evidence of decline of the foliage observed in the oak forest of Castelporziano. 


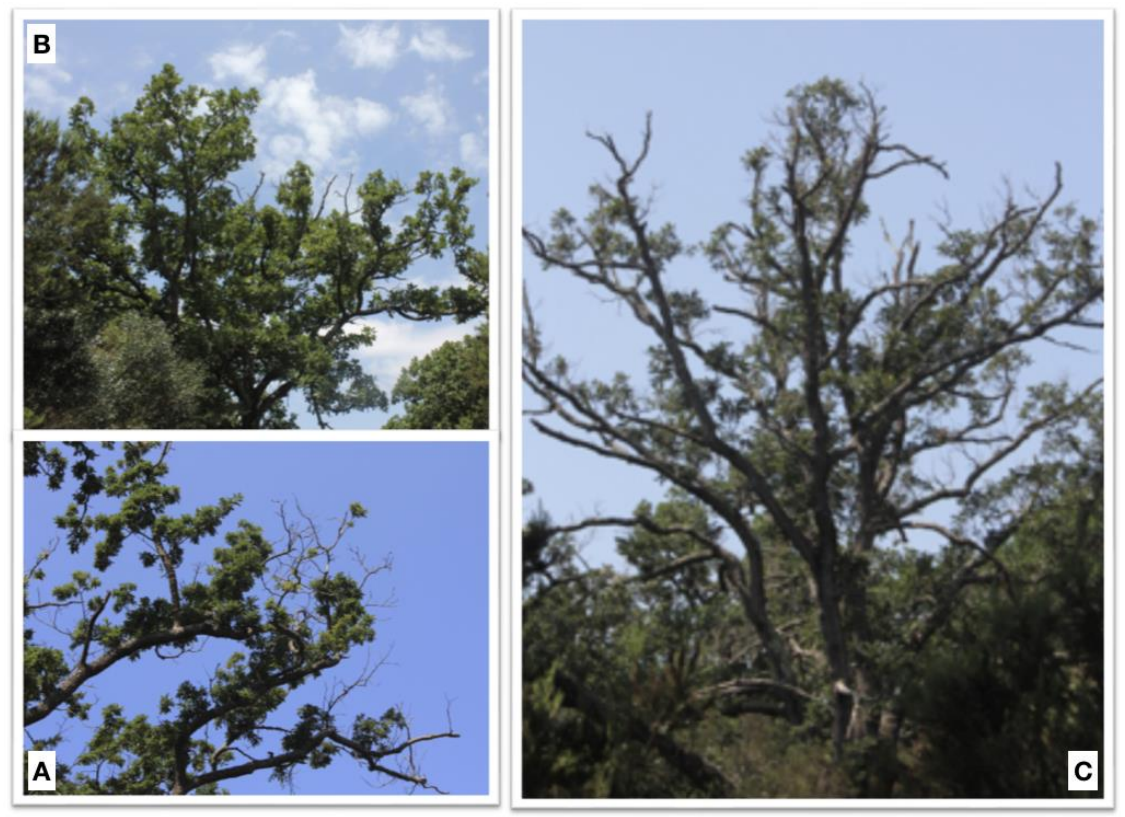

Figure 3. Examples of deciduous oak dieback detected in Castelporziano: (A) crown and shoot dieback; (B) leaf shedding; (C) growth loss and tree mortality.

\subsection{Remote Sensing Data and GIS Environment}

We used a set of Level 1C Sentinel-2 satellite images (bands 8 and 4), referring to the period: 18 July, 2015; 13 July, 2016; 12 February, 2017; and 26 July, 2017, provided by Copernicus open access Hub of the European Space Agency (ESA) and pre-processed using Sen2Cor provided by ESA, for atmospheric and topographic correction.

With regard to the Canopy Height Model (CHM) derived from the data of LIDAR for the area considered, this layer presents a spatial resolution of $1 \mathrm{~m}$, refers to the year 2010, and was provided by the Ministry of Environment and Protection of the Territory and Sea. All analysis in GIS environment were performed using the ArcMap 10.0 software by ESRI ${ }^{\circledR}$.

\subsection{Deciduous Oaks Canopy Layer}

Due to the high heterogeneity in terms of spatial distribution and silvicultural structures in Castelporziano oak forest, a preliminary analysis was carried out on the forest canopy cover, on a grid scale $\left(100 \mathrm{~m}^{2}\right)$, to specifically identify the cover of the deciduous oak canopy.

To achieve this, we used a Sentinel-2 derived grid with a spatial resolution of $10 \mathrm{~m}$. This allowed us to apply the NDVI specifically to detect the health condition of only the deciduous oak canopy.

To reach this goal, a georeferenced database was set up using (i) information provided by the Castelporziano forest management plan concerning the different heights referred to the dominant and dominated layers of the forest; (ii) CHM LiDAR data to separate dominant and dominated stand forest; and (iii) a diachronic set of multispectral Sentinel-2 images.

The analysis of the dominant and dominated layers of the forest was carried out by consulting the FMP of Castelporziano at the FMU scale, in terms of height referred to dominant forest (oak) and dominated forest layers (Mediterranean scrub and bare soil).

Using this information, we have separated the dominant layer from the dominated forest layer, reclassifying the CHM LiDAR data for each FMU, Table 1 shows the main silvicultural characteristics of the analyzed FMUs.

In this way, we obtained a binary layer that represents the dominant position of the forest characterized by evergreen and deciduous oaks. In Table 1 the main silvicultural parameters are shown for the eight FMU analyzed. 
Table 1. Main silvicultural characteristics of the FMUs analyzed.

\begin{tabular}{|c|c|c|c|c|c|c|c|}
\hline \multirow[b]{2}{*}{$\begin{array}{c}\text { Castelporziano Deciduous Oak } \\
\text { Forest Structures }\end{array}$} & \multirow[b]{2}{*}{ ID_Code } & \multirow[b]{2}{*}{$\begin{array}{l}\text { Surface } \\
\text { (Ha) }\end{array}$} & \multirow[b]{2}{*}{$\begin{array}{l}\text { Mean Oak } \\
\text { Canopy } \\
\text { Cover (\%) }\end{array}$} & \multicolumn{2}{|c|}{ Average Height (m) } & \multicolumn{2}{|c|}{ Forest Canopy Composition } \\
\hline & & & & $\begin{array}{c}\text { Dominant } \\
\text { Layer of } \\
\text { the Forest }\end{array}$ & $\begin{array}{c}\text { Dominated } \\
\text { Layer of } \\
\text { the Forest }\end{array}$ & $\begin{array}{l}\text { Deciduous } \\
\text { Oaks }\end{array}$ & $\begin{array}{l}\text { Non-Deciduous } \\
\text { Oaks }\end{array}$ \\
\hline $\begin{array}{l}\text { Transitional forests of deciduous } \\
\text { oaks and Ostrya carpinifolia }\end{array}$ & 21 & 156 & 73 & 9 & 7.5 & Qc; Qc; Qr; Qp & $\mathrm{Pl} ; \mathrm{Qi} ; \mathrm{Ac} ; \mathrm{Fo} ; \mathrm{Cr} ; \mathrm{Pp}$ \\
\hline $\begin{array}{l}\text { Transitional forests of deciduous } \\
\text { oaks and Mediterranea scrub }\end{array}$ & 22 & 181 & 62 & 8.5 & 6.5 & Qc; Qf; Qr; Qp & $\mathrm{E} ; \mathrm{Pl} ; \mathrm{Cr} ; \mathrm{Co}$ \\
\hline $\begin{array}{l}\text { Coppice of deciduous oaks with } \\
\text { Ostrya carpinifolia }\end{array}$ & 31 & 53 & 77 & 9.5 & 6.5 & Qf; Qr; Qc & $\mathrm{Ca} ; \mathrm{Um} ; \mathrm{Cb} ; \mathrm{Co}$ \\
\hline $\begin{array}{l}\text { Coppice of deciduous oaks with } \\
\text { Mediterranean scrub }\end{array}$ & 32 & 288 & 81 & 7.5 & 6 & Qf; Qc; Qr & $\begin{array}{l}\text { Pp; } \mathrm{Qs} ; \mathrm{Qcr} ; \mathrm{Qi} ; \mathrm{Pl} ; \mathrm{E} ; \\
\mathrm{Ct} ; \mathrm{E} ; \mathrm{Cr} ; \mathrm{Mc}\end{array}$ \\
\hline $\begin{array}{l}\text { Forest of deciduous oaks and } \\
\text { Mediterranean scrub }\end{array}$ & 43 & 664 & 18 & 11.5 & 4.5 & $\begin{array}{l}\text { Qf; Qc; Qpt; } \\
\text { Qp }\end{array}$ & $\begin{array}{c}\mathrm{P} ; \mathrm{Pl} ; \mathrm{Qs} ; \mathrm{Co} ; \mathrm{Qcr} ; \mathrm{Qi} ; \\
\text { Ln; Ac }\end{array}$ \\
\hline
\end{tabular}

Legend: Qp Quercus pubescens; Qf Quercus frainetto; Qr Quercus robur; Qc Quercus cerris; Qi Quercus ilex; Qcr Quercus crenata; Qs Qurcus suber; Co Carpinus orientalis; Pp Pinus pinea; Cb Carpinus betulus; Um Ulmus minor; Fo Fraxinus oxycarpa; Pl Phillyrea latifolia; Qpt Qurercus petraea; Ln Laurus nobilis; Ac Acer campestre; E Erica spp.; Cr Crataegus spp.; Mc Myrtus communis.

Finally, to remove evergreen canopy trees from our analysis, represented by evergreen oaks and stone pine, we compared the NDVI value detected for the winter and summer season using the 8 and 4 bands provided by Sentinel-2 data. The result of this methodology allowed us to obtain a grid mask relative to the canopy of the deciduous oak forest of Castelporziano. Figure 4 shows the methodological steps of this analysis.

The canopy mask obtained this way was subsequently validated with data derived from field surveys and photo-interpreted analyses.

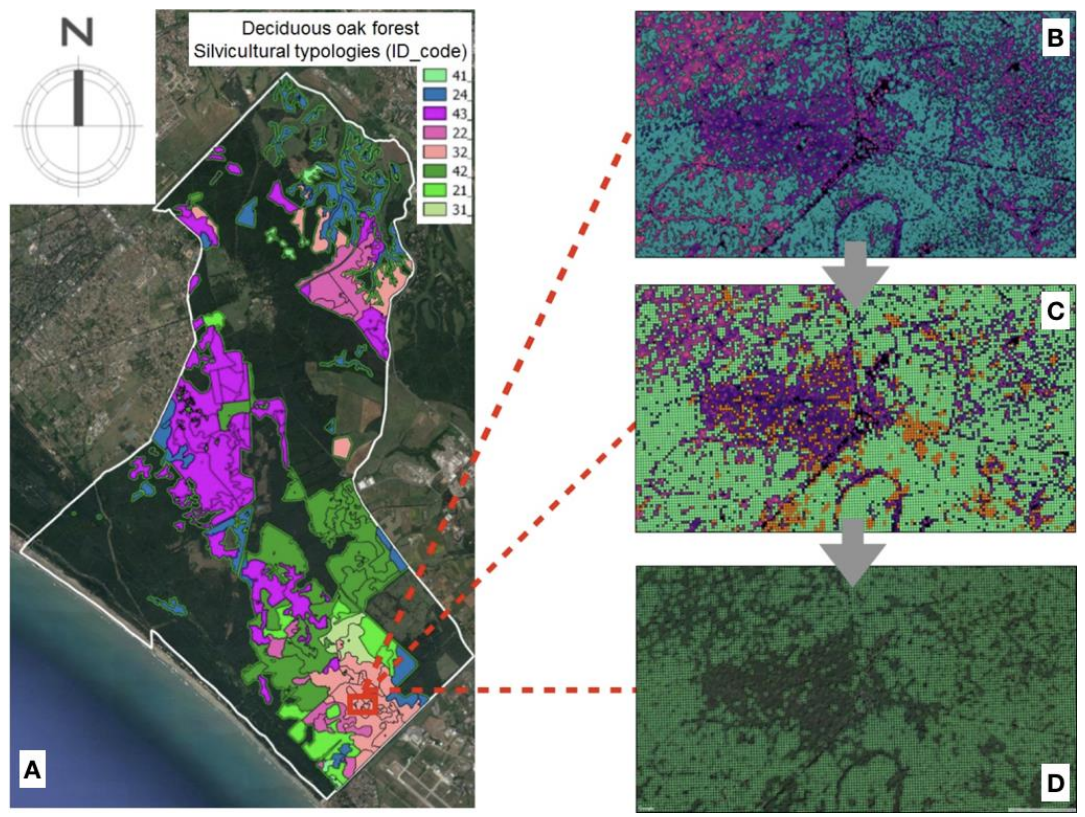

Figure 4. (A) Forest management plan (FMP) of Castelporziano, with subdivision of deciduous natural oak forest areas into eight silvicultural types (ID_code); (B) Light Detection and Ranging (LiDAR) data reclassification based on the height of the forest layer dominated in the FMU scale; (C) Normalized Difference Vegetation Index (NDVI) winter and summer difference scenario used to eliminate evergreen oaks and stone pine from the mask; (D) deciduous oak forest mask based on the Sentinel-2 grid scale. 


\section{Results}

Regarding the identification of the deciduous oak canopy cover, out of a total of 235,195 pixels, equivalent to an area of 3251 hectares, 91,744 pixels represent the deciduous oak canopy cover. According to Gongalton [28], this layer grid was validated referring to the kappa index of agreement (KIA) using 3737 pixels randomly distributed in the territory and validated by field surveys and by an analysis of aerial photos referring to 2017. The result obtained presents a coefficient of agreement KIA of over 0.87 . Concerning the error committed (13\%), equal to 487 pixels, $7 \%$ of them present as false positives.

According to the NDVI, using the multispectral Sentinel-2 images for the years 2015, 2016 and 2017, a widespread dieback was observed for the analyzed area. In this regard, the results show a decrease in the average NDVI value of the pixels ranging from 0.9 to 0.87 , from July 2015 to July 2016, and this decreases further to an average value of 0.85 in July 2017, Figure 5.

Overall, in the deciduous oak forest of Castelporziano, in the observation period a $5.5 \%$ decrease in the vegetative capacity was detected according to the NDVI values.
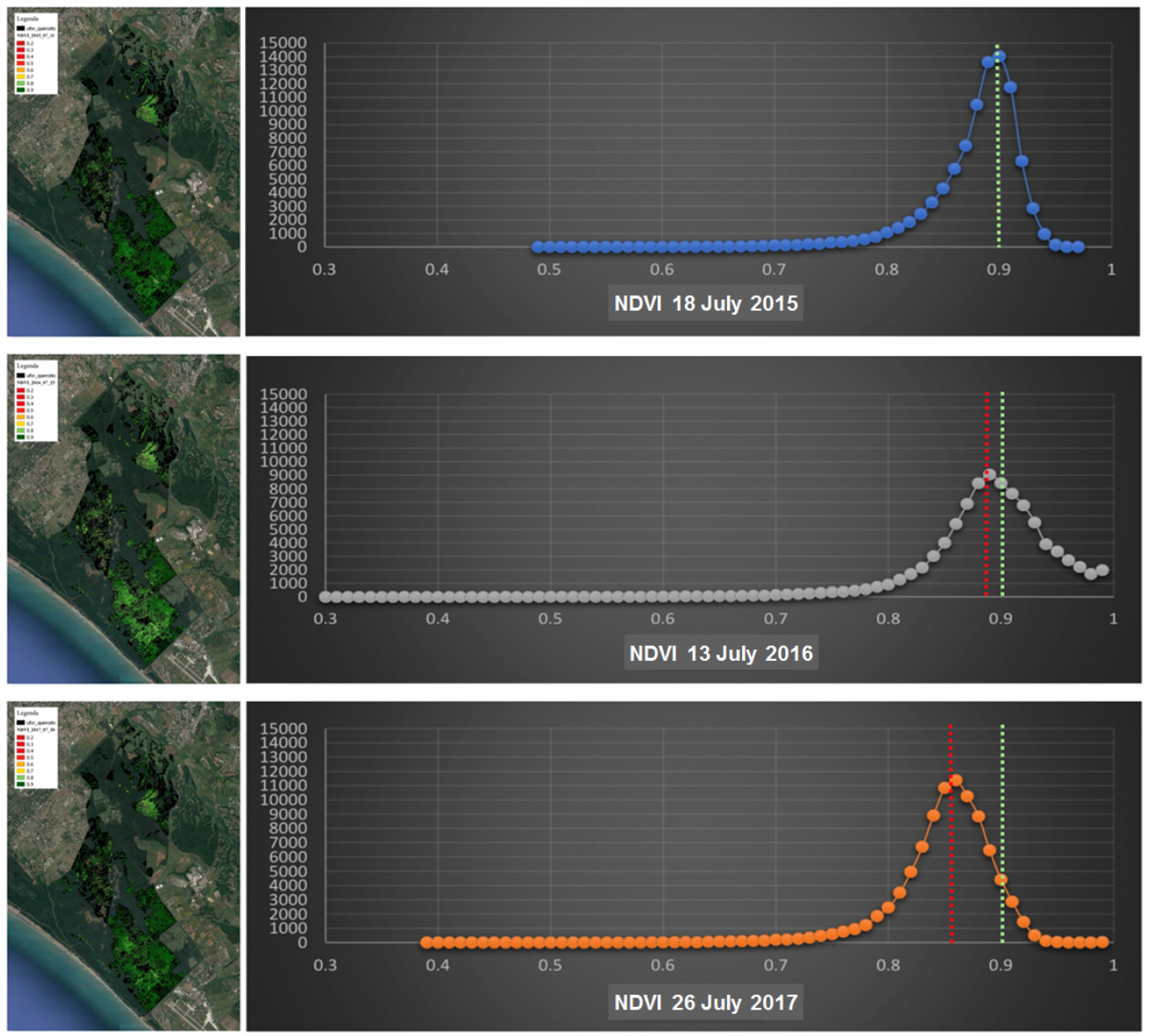

Figure 5. Castelporziano deciduous oak forest: Diachronic frequency of NDVI index (number of cells on y axis) for the observed period. The red dotted line indicates the average decrease in health condition monitored from 2015 (green dotted line).

\section{Discussion}

Nowadays, territory analysis by remote sensing data plays a fundamental role in forest management planning. This is thanks to the recent availability of open source multispectral satellite data such as those provided by Sentinel-2 satellite, whose spatial resolution and frequency in scenery acquisition represent a powerful tool for environmental monitoring. Recently, the availability of Very High Resolution (VHR) images and Unmanned Aerial Vehicle (UAV) based surveying represents an 
interesting tool in monitoring the natural environment. Unfortunately, due to their cost, low frequency in image acquisition and short autonomy in terms of working operation, they are not suitable to reach the goal of the present research which consists of planning an efficient, replicable and low cost monitoring tool.

In this framework, the Mediterranean environment, especially when represented by a natural forest such as in Castelporziano, still poses limiting factors in remote sensing applications due to the heterogeneity in tree canopy spatial distribution and the biodiversity of the dominant stand-layer of the forest. For these reasons, diachronic investigations concerning the vegetative health conditions using vegetational indices, for a specific forest typology (e.g., deciduous oak forest), necessarily involve a preventive investigation concerning forest dominant canopy aim to isolate the specific forest typology from the others.

In our study case, achievement in the GIS environment of a georeferenced mask (deciduous oak canopy cover) concerning the exact location of the deciduous oak canopy, allowed us to start monitoring this specific forest typology over time.

Regarding the novelty and importance of the present study, in terms of forestry management, the deciduous oak forest mask will represent an important georeferenced data base that, in time, will allow efficient and quick monitoring of the ancient coastal deciduous oak forest.

Concerning the NDVI values detected for the three scenarios considered, a diffuse crown dieback was observed in the Castelporziano deciduous oak forest. Overall, a 5.5\% decrease in vegetative capability was observed, and this result confirms the decline of the deciduous oak forest observed in the field during recent years. Furthermore, despite drought conditions which occurred during the observed period (especially in the summer of 2017), which contributed to the hydraulic stress and consequent decline in health condition, this result still gives evidence to the frailty of this ancient coastal Mediterranean landscape. Considering its uniqueness, this landscape must be the object of specific observation to provide useful information for planning efficient and swift actions that aim to ensure the sustainability and conservation of this natural environment.

\section{Conclusions}

This research concerns the application of remote sensing data in monitoring the vegetation health condition of a Mediterranean protected area. Using multispectral open source data as provided by the satellite Sentinel-2 according to the NDVI, and using the oak canopy cover layer as a spatial filter, an efficient and specific tool for monitoring the deciduous oak forest in Castelporziano was arranged. Furthermore, this tool, being based and calibrated on multispectral Sentinel-2 data, allows monitoring of the forest with a time frequency of about five days, thus enabling timely detection and monitoring of the health of the forest and, as a consequence, prompt planning of the best silvicultural solutions to preserve these environments.

As for other Mediterranean natural environments in Castelporziano, using open source satellite data with a spatial resolution of 100 square meters, the heterogeneous spatial distribution of the forest canopy still represents a limiting factor in applying VIs at the forest management scale. In this framework, the monitoring tool proposed for the deciduous oak forest, based on the pre-analysis of the forest canopy, represents a practical and replicable methodology that allows a low cost solution for monitoring natural environments.

The first results obtained in this research encourage the application of other VIs that can contribute to explaining the general and diffuse dieback detected by NDVI analysis. Furthermore, to better understand the oak decline detected in Castelporziano, NDVI responses will be correlated with the different forest types that characterize the Castelporziano deciduous oak forest.

Author Contributions: Conceptualization, F.R.; Data curation, C.G.; Investigation, C.G. and F.R.; Methodology, F.R.; Supervision, M.N.R.; Validation, F.R.; Writing-review \& editing, F.R.

Funding: This research has been funded by the Scientific-Technical Commission of Castelporziano and supported by the Management of the Estate of Castelporziano. 
Acknowledgments: The authors thank the General Secretariat of the Presidency of the Republic, the management of the Estate of Castelporziano, the Scientific-Technical Commission of Castelporziano that enabled these studies and the publication of the data.

Conflicts of Interest: The authors declare no conflict of interest.

\section{References and Note}

1. IPCC. Climate Change 2014: Impacts, Adaptation, and Vulnerability. Part A: Global and Sectoral Aspects. Contribution of Working Group II to the Fifth Assessment Report of the Intergovernmental Panel on Climate Change; Cambridge University Press: Cambridge, UK, 2014; p. 1435.

2. FAO. Decline and Dieback of Trees and Forest; FAO Forestry Paper; FAO: Rome, Italy, 1994.

3. Maselli, F. Monitoring forest conditions in a protected Mediterranean coastal area by the analysis of multiyear NDVI data. Remote Sens. Environ. 2004, 89, 423-433. [CrossRef]

4. Allen, C.D.; Macalady, A.K.; Chenchouni, H.; Bachelet, D.; McDowell, N.; Vennetier, M.; Kizberger, T.; Rigling, A.; Breshears, D.D.; Hogg, E.H.; et al. A global overview of drought and heat-induced tree mortality reveals emerging cli- mate change risks for forests. For. Ecol. Manag. 2010, 259, 660-684. [CrossRef]

5. Colangelo, M.; Camarero, J.J.; Battipaglia, G.; Borghetti, M.; De Micco, V.; Gentilesca, T.; Ripullone, F. A multi-proxy assessment of dieback causes in a Mediterranean oak. Tree Physiol. 2017, 37, 617-631. [CrossRef] [PubMed]

6. Starkey, D.A.; Steven, W. Site Factor and Condition Associated with Oak Decline in SouthernUpland Hardwood Forests. Paper Presented at the Seventh Central Hardwood Forest Conference, Carbondale, IL, USA, 5-8 March 1989.

7. McDowell, N.; Pockman, W.T.; Allen, C.D. Mechanism of plant survival and mortality during drought: Why do some plant survive while others succumb to drought? New Phytol. 2008, 178, 719-739. [CrossRef] [PubMed]

8. Gentilesca, T.; Camarero, J.J.; Colangelo, M.; Nolè, A.; Ripullone, F. Drought-induced oak decline in the western Mediterranean region: An overview on current evidences, mechanisms and management options to improve forest resilience. iForest Biogeosci. For. 2017, 10, 796-806. [CrossRef]

9. Carleer, A.; Wolff, E. Exploitation of Very High Resolution Satellite Data for Tree Species Identification. Photogramm. Eng. Remote Sens. 2004, 70, 135-140. [CrossRef]

10. Carreiras, J.M.B.; Pereira, J.M.C.; Pereira, J.S. Estimation of tree canopy cover in evergreen oak woodlands using remote sensing. For. Ecol. Manag. 2006, 223, 45-53. [CrossRef]

11. Donmez, C.; Berberoglu, S.; Erdogan, M.A.; Tanriover, A.A.; Cilek, A. Response of the regression tree model to high resolution remote sensing data for predicting percent tree cover in a Mediterranean ecosystem. Environ. Monit. Assess. 2015, 184,1-12. [CrossRef] [PubMed]

12. Frampton, W.J.; Dash, J.; Watmough, G.; Milton, E.G. Evaluating the capabilities of Sentinel-2 for quantitative estimation of biophysical variables in vegetation. J. Photogramm. Remote Sens. 2013, 82, 83-92. [CrossRef]

13. Modica, G.; Solano, F.; Merlino, A.; Di Fazio, S.; Barreca, F.; Laudari, L.; Fichera, C.R. Using Landsat 8 imagery in detecting cork oak (Quercus suber L.) woodlands: A case study in Calabria (Italy). J. Agric. Eng. Res. 2016, 47, 205-215. [CrossRef]

14. Bannari, A.; Morin, D.; Bonn, F. A review of Vegetation Indices. Remote Sens. Rev. 1995, 13, 95-120. [CrossRef]

15. Vina, A.; Gitelson, A.A.; Nguy-Robertson, A.; Peng, Y. Comparison of different vegetational indices for the remote assessment of green leaf area index of crops. Remote Sens. Environ. 2011, 115, 3468-3478. [CrossRef]

16. Costa, A.; Pereira, H.; Madeira, M. Analysis of spatial patterns of oak decline in cork oak woodlands in Mediterranean conditions. Ann. For. Sci. 2010, 67, 194-204. [CrossRef]

17. Cicuendez, V.; Litago, V.; Huesca, M.; Rodriguez-Rastrero, M.; Recuero, L.; Merino-de-Miguel, S.; Palacios-Orueta, A. Assessment of the gross primary production dynamics of a Mediterranean holm oak forest by remote sensing time series analysis. Agrofor. Syst. 2015, 89, 491-510. [CrossRef]

18. Gooshbor, L.; Pir Bavaghar, M.; Amanollahi, J.; Ghobari, H. Monitoring Infestations of Oak Forests by Tortrix viridana (Lepidoptera: Tortricidae) using Remote Sensing. Plant Prot. Sci. 2016, 52, 270-276.

19. Havasova, M.; Bucha, T.; Ferencik, J.; Jakus, R. Applicability of a vegetation indices-based method to map bark beetle outbreaks in the High Tatra Mountains. Ann. For. Res. 2015, 58, 295-310. [CrossRef] 
20. Ogaya, R.; Barbeta, A.; Basnou, C. Satellite data as indicators of tree biomass growth and forest dieback in a Mediterranean holm oak forest. Ann. For. Sci. 2015, 72, 135-144. [CrossRef]

21. Recanatesi, F. Variations in land-use/land-cover changes (LULCCs) in a peri-urban Mediterranean nature reserve: The estate of Castelporziano (Central Italy). Rendiconti Lincei 2014, 26, 517-526. [CrossRef]

22. Pratesi, F. Castelporziano: History of a forest. Rendiconti Lincei 2015, 26, 305-310. [CrossRef]

23. Giordano, E.; Capitoni, B.; Eberle, A.; Maffei, L.; Musicanti, A.; Recanatesi, F.; Torri, V. Piano di gestione forestale della Tenuta Presidenziale di Castelporziano [Forest Management Plan of the Presidential Estate of Castelporziano]. Segretariato Generale della Presidenza della Repubblica-Commissione Tecnico-Scientifica della Tenuta Presidenziale di Castelporziano, 2010, 3, 131-398.

24. Scrinzi, G.; Presutti Saba, E.; Colle, G. Indirizzi Gestionali E Obiettivi D'intervento Per Le Classi Colturali Della Foresta Della Tenuta Presidenziale Di Castelporziano; Accademia Nazionale delle Scienze: Roma, Italy, 2016.

25. Manes, F.; Seufert, G.; Vitale, M. Ecophysiological studies of Mediterranean plant species at the Castelporziano Estate. Atmos. Environ. 1997, 31, 51-60. [CrossRef]

26. Moretti, V.; Salvati, L. Soil Water Availability and the Renewal of Oak Forest Stands in a Coastal Mediterranean Area: An Experimental Study. Int. J. Environ. Res. 2014, 8, 577-582.

27. Recanatesi, F.; Petroselli, A.; Ripa, M.N.; Leone, A. Assessment of stormwater runoff management practices and BMPs under soil sealing: A study case in a peri-urban watershed of the metropolitan area of Rome (Italy). J. Environ. Manag. 2017, 201, 6-18. [CrossRef] [PubMed]

28. Congalton, R.G. A review of assessing the accuracy of classifications of remotely sensed data. Remote Sens. Environ. 2014, 37, 35-46. [CrossRef]

(c) 2018 by the authors. Licensee MDPI, Basel, Switzerland. This article is an open access article distributed under the terms and conditions of the Creative Commons Attribution (CC BY) license (http://creativecommons.org/licenses/by/4.0/). 